\title{
FACTORS AFFECTING ACCOUNTING INFORMATION DISCLOSURE AND TRANSPARENCY IN ESTIMATING THE VOLATILITY OF MARKET RISK OF VIET NAM LISTED FIRMS IN TELECOM AND EDUCATION INDUSTRY AFTER THE LOW INFLATION PERIOD
}

\section{HOANG THANH HANH}

Academy of Finance, Vietnam

ABSTRACT

We recognized many factors affecting disclosure of accounting information and have impacts on risk level of business, such as: the following factors influenced on the disclosure level: tax rate, financial leverage, acquiring company size, recognized percentage of overprice for expected future profitability in relation to the transaction value. It is the time we need transparency in accounting information disclosure as well as risk management policies.

The Vietnam economy and telecom and education industry have gained lots of achievements after the financial crisis 2007-2011, until it reached a low inflation rate of $0.6 \%$ in 2015. Telecom and education companies face challenges in expanding Vietnam market such as pricing policy and supporting services, etc. This paper measures the volatility of market risk in Viet Nam telecom and education industry after this period (2015-2017). The main reason is the vital role of the telecom and education company group in Vietnam in the economic development and growth in recent years always go with risk potential and risk control policies.

This research paper aims to figure out how much increase or decrease in the market risk of Vietnam telecom and education firms during the post-low inflation period 2015-2017.

First, by using quantitative combined with comparative data analysis method, we find out the risk level measured by equity beta mean in the telecom and education industry is acceptable, i.e it is little lower than (<) 1.

Then, one of its major findings is the comparison between risk level of telecom and education industry during the financial crisis 2007-2009 compared to those in the post-low inflation time 2015-2017. In fact, the research findings show us market risk fluctuation, measured by asset and equity beta var, during the post-low inflation time has increased moderately.

Finally, this paper provides some ideas that could provide companies and government more evidence in establishing their policies in governance. This is the complex task but the research results shows us warning that the market risk volatility might be higher during the post-low inflation period 2015-2017. And our conclusion part will recommend some policies and plans to deal with it. Finding new potential markets and credit and financing policies are among directions for telecom and education companies.

Specifically, it also proposes suggestions for enhancing disclosure policy of accounting information and risk policies of businesses.

KEYWORDS: Risk Management, Transparency, Asset Beta, Financial Crisis, Telecom and Education Industry, Policy. JEL Classification Numbers: G00, G390, C83

Received: Jun 08, 2020; Accepted: Jun 28, 2020; Published: Sep 03, 2020; Paper Id.: IJMPERDJUN20201035 


\section{INTRODUCTION}

Throughout many recent years, Viet Nam telecom \& education market is evaluated as one of active markets, which has certain positive effect for the economy. The development of telecom \& education industry goes parallel with financial market and economic growth. Quality of products is trying to achieve both effectiveness and easy to use.

Generally speaking, central banks aim to maintain inflation around $2 \%$ to $3 \%$. Increases in inflation significantly beyond this range can lead to possible hyperinflation, a devastating scenario in which inflation rises rapidly out of control. Looking at exhibit 1, we can see the Vietnam economy has controlled inflation well. High inflation might lead to higher lending rate and harm the telecom \& education industry because of rising material price.

This study will calculate and figure out whether the market risk level during the post-low inflation time (2015-17) has increased or decreased, in telecom \& education industry, compared to those statistics in the financial crisis time (20072009).

The paper is organized as follows: after the introduction it is the research issues, literature review, conceptual theories and methodology. Next, section 3 will cover main research findings/results. Section 4 gives us some discussion and conclusion and policy suggestion will be in the section 5 .

\section{BODY OF MANUSCRIPT}

\section{Research Issues}

The scope of this study are:

- Issue 1: Whether the risk level of telecom \& education firms under the different changing scenarios in post-low inflation period 2015-2017 increase or decrease so much, compared to in financial crisis 2007-2009?

- Issue 2: Because Viet Nam is an emerging and immature financial market and the stock market still in the starting stage, whether the dispersed distribution of beta values become large in the different changing periods in the telecom \& education industry.

This paper also tests three (3) below hypotheses:

- Hypothesis 1: Comparing two (2) periods, during the financial crisis impact, the beta or risk level of listed companies in telecom \& education industry will relatively higher than those in the post-low inflation environment.

- Hypothesis 2: Because Viet Nam is an emerging and immature financial market and the stock market still in the recovering stage, there will be a large disperse distribution in beta values estimated in the telecom \& education industry.

- Hypothesis3: With the above reasons, the mean of equity and asset beta values of these listed telecom \& education firms tend to impose a high risk level, i.e., beta should higher than (>) 1. This hypothesis is based on the context of emerging markets including Viet Nam where there lacks of sufficient information and data disclosure although it might have high growth rate. 


\section{LITERATURE REVIEW}

Fama, Eugene F., and French, Kenneth R., (2004) also indicated in the three factor model that "value" and "size" are significant components which can affect stock returns. They also mentioned that a stock's return not only depends on a market beta, but also on market capitalization beta. The market beta is used in the three factor model, developed by Fama and French, which is the successor to the CAPM model by Sharpe, Treynor and Lintner.

Dimitrov (2006) documented a significantly negative association between changes in financial leverage and contemporaneous risk-adjusted stock returns.

Umar (2011) found that firms which maintain good governance structures have leverage ratios that are higher (forty-seven percent) than those of firms with poor governance mechanisms per unit of profit. Chen et all (2013) supported regulators' suspicions that over-reliance on short-term funding and insufficient collateral compounded the effects of dangerously high leverage and resulted in undercapitalization and excessive risk exposure for Lehman Brothers. The model reinforces the importance of the relationship between capital structure and risk management. And Gunaratha (2013) revealed that in different industries in Sri Lanka, the degree of financial leverage has a significant positive correlation with financial risk.

During the financial crisis 2007-2009 in Viet Nam and global financial markets, high inflation causing high lending rates have created risks for many industries such as real estate and the whole economy. Mohamad et all (2014) showed that financial risk is vital through using both return on asset and return on equity in the performance equation. This result also implied that we cannot avoid the inverse relation of financial risk and performance; therefore, bank system would be better to make a trade-off between risk and performance.

Wang et all (2014) presented results showing that firms with long-term institutional investors receive significantly positive abnormal returns around the offering announcement.

Then, Gunarathna (2016) revealed that whereas firm size negatively impacts on the financial risk, financial leverage and financial risk has positive relationship.

Hami (2017) showed that financial depth has been affected negatively by inflation in Iran during the observation period.

\section{Conceptual Theories}

Positive sides of low inflation: Low (not negative) inflation reduces the potential of economic recession by enabling the labor market to adjust more quickly in a downturn, and reduces the risk that a liquidity trap prevents monetary policy from stabilizing the economy. This is explaining why many economists nowadays prefer a low and stable rate of inflation. It will help investment, encourage exports and prevent boom economy.

Negative side of low inflation: it leads to low aggregate demand and economic growth, recession potential and high unemployment. Production becomes less vibrant. Low inflation makes real wages higher. Workers can thus reduce the supply of labor and increase rest time. On the other hand, low product prices reduce production motivation.

The central bank can use monetary policies, for instance, increasing interest rates to reduce lending, control money supply or the Ministry of finance and the government can use tight fiscal policy (high tax) to achieve low inflation. 
Financial and credit risk in the bank system can increase when the financial market becomes more active and bigger, esp. with more international linkage influence. This affects to risk increasing in telecom \& education sector. Hence, central banks, commercial banks, telecom \& education firms and the government need to organize data to analyze and control these risks, including market risk.

\section{METHODOLOGY}

We use the data from the stock exchange market in Viet Nam (HOSE and HNX) during the financial crisis 2007-2009 period and the post - low inflation time 2015-2017 to estimate systemic risk results. We perform both fundamental data analysis and financial techniques to calculate equity and asset beta values.

In this study, analytical research method and specially, comparative analysis method is used, combined with quantitative data analysis. Analytical data is from the situation of listed telecom \& educationfirms in VN stock exchange.

Specifically, stock price data is from live data on HOSE stock exchange during 3 years 2015-2017, which presents the low inflation environment. Then, we use both analytical and summary method to generate analytical results from data calculated.

Finally, we use the results to suggest policy for both these enterprises, relevant organizations and government.

\section{MAIN RESULTS}

\section{General Data Analysis}

We get some analytical results form the research sample with18 listed firms in the telecom \& education market with the live date from the stock exchange.

\section{Empirical Research Findings and Discussion}

In the below section, data used are from total 18 listed telecom \& education companies on VN stock exchange (HOSE and HNX mainly). Different scenarios are created by comparing the calculation risk data between 2 periods: the post - low inflation period 2015-2017 and the financial crisis 2007-2009.

Market risk (beta) under the impact of tax rate, includes: 1) equity beta; and 2) asset beta. We model our data analysis as in the below figure:

\begin{tabular}{|c|c|c|c|c|}
\hline & $\begin{array}{l}\text { Risk level } \\
\text { (equity beta) }\end{array}$ & $\begin{array}{l}\text { Risk level } \\
\text { (asset beta) }\end{array}$ & Other measures & Gap \\
\hline$\frac{\text { Post }- \text { low inflation period }}{\text { Financial crisis time }}$ & Scenario & Scenario & Scenario & Analysis \\
\hline
\end{tabular}

Figure 1: Analyzing Market Risk Under Two (2) Scenarios: Post - Low Inflation Period 2015-2017 Compared to the Financial Crisis 2007-2009 

Viet Nam Listed Firms in Telecom and Education Industry After the Low Inflation Period

Table 1: The Volatility of Market Risk (beta) of Telecom and Education Industry in the Post- Low Inflation Period 2015-2017

\begin{tabular}{|c|c|c|c|c|c|}
\hline \multirow[b]{2}{*}{ Order No. } & \multirow[b]{2}{*}{$\begin{array}{c}\text { Company stock } \\
\text { code }\end{array}$} & \multicolumn{2}{|c|}{ 2015-2017 (post - low inflation) } & \multirow[b]{2}{*}{ Financial leverage } & \multirow[b]{2}{*}{ Note } \\
\hline & & Equity beta & $\begin{array}{c}\text { Asset beta (assume debt } \\
\text { beta }=0 \text { ) }\end{array}$ & & \\
\hline 1 & ECI & -0.007 & -0.006 & $16.5 \%$ & \multirow{18}{*}{$\begin{array}{c}\text { assume debt beta }= \\
0 ; \text { debt ratio as in } \\
\text { F.S 2015; FL } \\
\text { calculated as total } \\
\text { debt/total capital }\end{array}$} \\
\hline 2 & INN & & & & \\
\hline 3 & PTP & -0.049 & -0.037 & $25.9 \%$ & \\
\hline 4 & DHI & & & & \\
\hline 5 & IHK & & & & \\
\hline 6 & HTP & 0.927 & 0.861 & $7.2 \%$ & \\
\hline 7 & TPH & -0.121 & -0.072 & $41.0 \%$ & \\
\hline 8 & IN4 & & & & \\
\hline 9 & $\mathrm{ADC}$ & 0.282 & 0.114 & $59.4 \%$ & \\
\hline 10 & HST & 0.148 & 0.095 & $35.3 \%$ & \\
\hline 11 & SGD & -0.495 & -0.376 & $24.0 \%$ & \\
\hline 12 & DAE & 0.029 & 0.021 & $27.6 \%$ & \\
\hline 13 & HEV & -0.091 & -0.073 & $19.7 \%$ & \\
\hline 14 & ALT & -0.451 & -0.390 & $13.4 \%$ & \\
\hline 15 & EFI & -0.665 & -0.659 & $0.8 \%$ & \\
\hline 16 & EID & 0.162 & 0.095 & $41.3 \%$ & \\
\hline 17 & DAD & 0.401 & 0.324 & $19.1 \%$ & \\
\hline 18 & SED & 0.576 & 0.375 & $34.9 \%$ & \\
\hline
\end{tabular}

Table 2: The Statistics of Volatility of Market Risk (beta) of Telecom and Education Industry in the Post- Low Inflation Period 2015-2017

\begin{tabular}{|c|c|c|}
\hline & \multicolumn{2}{|c|}{$\mathbf{2 0 1 5 - 2 0 1 7}$ (post - low inflation) } \\
\hline Statistic results & Equity beta & Asset beta (assume debt beta = 0) \\
\hline MAX & 0.927 & 0.861 \\
\hline MIN & -0.665 & -0.659 \\
\hline MEAN & 0.046 & 0.020 \\
\hline VAR & 0.1820 & 0.1349 \\
\hline \multicolumn{2}{|c|}{ Note: Sample size : 18} \\
\hline
\end{tabular}

Table 3: The Comparison of Volatility of Market Risk (beta) of Telecom and Education Industry in the Post- Low Inflation Period 2015-2017 and the Financial Crisis 2007-2009

\begin{tabular}{|c|c|c|c|c|c|c|}
\hline \multirow[b]{2}{*}{ Order No. } & \multirow[b]{2}{*}{$\begin{array}{c}\text { Company stock } \\
\text { code }\end{array}$} & \multicolumn{2}{|c|}{ 2007-2009 (financial crisis) } & \multicolumn{2}{|c|}{ 2015-2017 (post - low inflation) } & \multirow[b]{2}{*}{ Note } \\
\hline & & Equity beta & $\begin{array}{c}\text { Asset beta (assume debt } \\
\text { beta }=0)\end{array}$ & Equity beta & $\begin{array}{c}\text { Asset beta (assume debt } \\
\text { beta }=0 \text { ) }\end{array}$ & \\
\hline 1 & \begin{tabular}{|l|} 
ECI \\
\end{tabular} & 0.471 & 0.351 & -0.007 & \begin{tabular}{|c|}
-0.006 \\
\end{tabular} & \multirow{18}{*}{$\begin{array}{c}\text { assume debt beta } \\
=0 \text {; debt ratio as } \\
\text { in F.S } 2015 \text { and } \\
2008\end{array}$} \\
\hline 2 & INN & 0.467 & 0.25 & 0.000 & 0.000 & \\
\hline 3 & PTP & 0.425 & 0.203 & -0.049 & -0.037 & \\
\hline 4 & DHI & 0.894 & 0.66 & 0.000 & 0.000 & \\
\hline 5 & IHK & 0.593 & 0.34 & 0.000 & 0.000 & \\
\hline 6 & HTP & 1.035 & 0.802 & 0.927 & 0.861 & \\
\hline 7 & TPH & 0.924 & 0.411 & -0.121 & -0.072 & \\
\hline 8 & IN4 & 0.315 & 0.189 & 0.000 & 0.000 & \\
\hline 9 & $\mathrm{ADC}$ & 0.513 & 0.258 & 0.282 & 0.114 & \\
\hline 10 & HST & 0.654 & 0.455 & 0.148 & 0.095 & \\
\hline 11 & SGD & 1.180 & 0.63 & -0.495 & -0.376 & \\
\hline 12 & DAE & 1.013 & 0.399 & 0.029 & 0.021 & \\
\hline 13 & HEV & 0.869 & 0.596 & -0.091 & -0.073 & \\
\hline 14 & ALT & 0.772 & 0.617 & -0.451 & -0.390 & \\
\hline 15 & EFI & 0.447 & 0.422 & -0.665 & -0.659 & \\
\hline 16 & EID & 0.599 & 0.433 & 0.162 & 0.095 & \\
\hline 17 & DAD & 0.868 & 0.588 & 0.401 & 0.324 & \\
\hline 18 & SED & 0.319 & 0.147 & 0.576 & 0.375 & \\
\hline
\end{tabular}


Table 4: The Difference between Volatility of Market Risk (beta) of Telecom and Education Industry in the PostLow Inflation Period 2015-2017 and the Financial Crisis 2007-2009

\begin{tabular}{|c|c|c|c|c|}
\hline & & \multicolumn{2}{|c|}{ GAP (+/-) 2015-17 compared to 2007-09 } & Asset beta (assume debt beta = 0) \\
\hline Order No. & Company stock code & Equity beta & -0.357 \\
\hline 1 & ECI & -0.478 & -0.250 \\
\hline 2 & INN & -0.467 & -0.240 \\
\hline 3 & PTP & -0.474 & -0.660 \\
\hline 4 & DHI & -0.894 & -0.340 \\
\hline 5 & IHK & -0.593 & 0.059 \\
\hline 6 & HTP & -0.108 & -0.483 \\
\hline 7 & TPH & -1.045 & -0.189 \\
\hline 8 & IN4 & -0.315 & -0.144 \\
\hline 9 & ADC & -0.231 & -0.360 \\
\hline 10 & HST & -0.506 & -1.006 \\
\hline 11 & SGD & -1.675 & -0.378 \\
\hline 12 & DAE & -0.984 & -0.669 \\
\hline 13 & HEV & -0.960 & -1.007 \\
\hline 14 & ALT & -1.223 & -1.081 \\
\hline 15 & EFI & -1.112 & -0.338 \\
\hline 16 & EID & -0.437 & -0.264 \\
\hline 17 & DAD & -0.467 & 0.228 \\
\hline 18 & SED & 0.257 & \\
\hline
\end{tabular}

Table 5: Statistics of Volatility of Market Risk (beta) of Telecom and Education Industry in the Post- Low Inflation Period 2015-2017 Compared to those in the Financial Crisis 2007-2009

\begin{tabular}{|c|c|c|c|c|c|c|}
\hline \multirow[b]{2}{*}{$\begin{array}{l}\text { Statistic } \\
\text { results }\end{array}$} & \multicolumn{2}{|c|}{ 2007-2009 (crisis) } & \multicolumn{2}{|c|}{$\begin{array}{l}\text { 2015-2017 (post - low } \\
\text { inflation) }\end{array}$} & \multicolumn{2}{|c|}{$\begin{array}{c}\text { GAP }(+/-) \text { 2015-17 compared to 2007- } \\
09\end{array}$} \\
\hline & Equity beta & $\begin{array}{l}\text { Asset beta (assume } \\
\text { debt beta }=0 \text { ) }\end{array}$ & Equity beta & $\begin{array}{c}\text { Asset beta } \\
(\text { assume debt } \\
\text { beta }=0)\end{array}$ & Equity beta & $\begin{array}{c}\text { Asset beta (assume debt } \\
\text { beta }=0)\end{array}$ \\
\hline MAX & 1.180 & 0.802 & 0.927 & 0.861 & -0.253 & 0.059 \\
\hline MIN & 0.315 & 0.147 & -0.665 & -0.659 & -0.980 & -0.806 \\
\hline MEAN & 0.687 & 0.431 & 0.046 & 0.020 & -0.640 & -0.411 \\
\hline VAR & 0.0697 & 0.0345 & 0.182 & 0.135 & 0.112 & 0.100 \\
\hline
\end{tabular}

Based on the above calculation result table, we analyze data as follows:

Firstly, we see in the table 1 that more telecom and education firms ( 7 over 18firms) have equity beta values lower $(<)$ than 1 , which means risk level acceptable. There are 7 firms with negative equity beta $(<0)$.

And table 2 provides evidence for us to see that equity beta mean of the sample is 0.046 , just little lower than $(<)$ 1. It is acceptable.

Then, looking at the table 3 , we recognize that there are 7 firms with equity beta values $<0$ in the post-low inflation period 2015-17 and no firm with negative equity beta valuesin the financial crisis 2007-2009. Also, there are 3 firms with equity beta $>1$ in the crisis 2007-09 while no firm with equity beta $>1$ in the post-L inflation time.

Next, table 5 shows that equity beta var in the post- low inflation period are higher (>) than those in the financial crisis 2007-2009.

In addition to, looking at the below chart 1 , we can find out: 
More clearly, Value of equity beta var in the post-low inflation 2015-2017 is higher (>) than those in the crisis 2007-2009 while equity beta mean and asset beta mean are smaller $(<)$ than those in the financial crisis 2007-2009. It means that the level of risk in the post - low inflation period 2015-17 is lower in general and in average, although the fluctuation in risk level measured by equity beta var is much higher during the post-low inflation time.

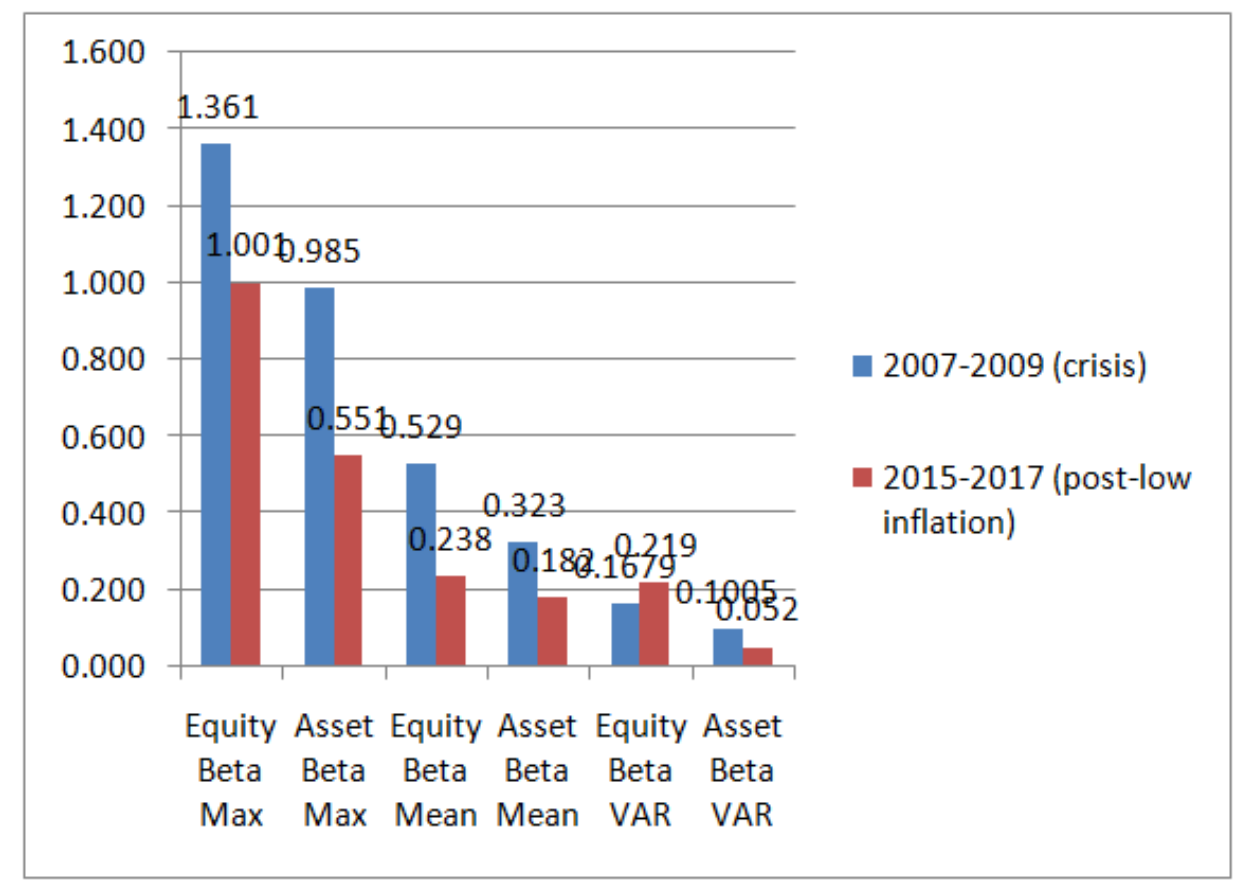

Chart 1: Statistics of Market Risk (beta) in VN Telecom and Education Industry in the

Post - Low Inflation Period 2015-2017 Compared to the Financial Crisis 2007-2009.

\section{DISCUSSION FOR FURTHER RESEARCHES}

We can continue to analyze risk factors behind the risk scene (risk fluctuation increasing, shown by equity beta var as above analysis) in order to recommend suitable policies and plans to control market risk better.

\section{CONCLUSIONS AND POLICY SUGGESTION}

In general, telecom and education company group in Vietnam has been contributing significantly to the economic development and GDP growth rate of more than 6-7\% in recent years. The above analysis shows us that despite of market risk decreasing, risk volatility (aset and equity beta var) is increasing significantly during the post-low inflation period. Telecom and education firms in Vietnam need to continue enhancing their corporate governance system, structure and mechanisms, as well as their competitive advantage to control risk better. Also, they need to reduce risk of quality of devices and reputation risk of telecom \& education companies. Telecom \& education companies need to identify demand from 4.0 technology era to enhance quality of laborers for a higher level of automation and offer better products for business management.

This research paper provides evidence that the market risk potential might be lower in 2015-2017 post-low inflation period (looking again chart 1 - equity beta mean values), while the Exhibit 3 also suggests that the credit growth rate increased in 2016 and slightly decrease in later years (2017-2018). It means that the local economy is trying to control credit growth reasonably, however we need to analyze risk factors more carefully to reduce more market risk. 
Looking at the above chart 1 , the result rejects the hypothesis 3 mentioning that the mean of equity and asset beta values of these listed telecom \& education firms tend to impose a little high risk level, i.e., beta should higher than (>) 1. Because the equity beta mean is lower in the post-low (L) inflation period, it supports the hypothesis 1 saying that comparing two (2) periods, during the financial crisis impact, the beta or risk level of listed companies in telecom \& education industry will relatively higher than those in the post-low inflation environment. Additionally, the above result supports the hypothesis 2 stating that because Viet Nam is an emerging and immature financial market and the stock market still in the recovering stage, there will be a large disperse distribution in beta values estimated in the telecom $\&$ education industry.

Last but not least, as it generates the warning that the risk fluctuation might be much higher in the post-low inflation period, the government and relevant bodies such as Ministry of Finance and State Bank of Vietnam need to consider proper policies (including a combination of fiscal, monetary, exchange rate and price control policies) aiming to reduce the risk volatility and hence, help the telecom \& education company group as well as the whole economy become more stable in next development stage. The Ministry of Finance continue to increase the effectiveness of fiscal policies and tax policies which are needed to combine with other macro policies at the same time. The State Bank of Viet Nam continues to increase the effectiveness of capital providing channels for telecom \& educationcompanies as we could note that in this study,debt leverage has impacts on reducing risk level.

Finally, this study opens some new directions for further researches in risk control policies in telecom \& education company system as well as in the whole economy. Telecom \& education companies need to do a better pricing strategy and provide extra services to help Vietnam enterprises to build standardized processes.

\section{Recommendations for Better Accounting Information Disclosure and Transparency}

For managing better risk, we need to enhance accounting information disclosure and transparency policies, for instance: In order to improve the level of information disclosure on financial statements, the private enterprises themselves need to increase their sense of responsibility; Investment in developing information systems in enterprises; Complete corporate governance system and build an internal audit system in the company. For governmental agencies, it is necessary to improve the legal environment in the field of accounting, auditing and information disclosure such as: Amending accounting standards and auditing in the direction of approaching international accounting, etc.standards. ; Completing the regulations on information presentation and disclosure on the stock market;

Accounting information transparency is also the key to fighting corruption, increasing public confidence, and enabling more accountability mechanisms.

\section{ACKNOWLEDGEMENTS}

I would like to take this opportunity to express my warm thanks to Board of Editors my family, colleaguesin assisting convenient conditions for my research paper.

\section{REFERENCES}

1. Allen, F., and Gale, D. (1992). Stock Price Manipulation, Review of Financial Studies.

2. Basu, Devraj., and Streme, Alexander. (2007). CAPM and Time-Varying Beta: The Cross-Section of Expected Returns, SSRN Working paper series 
3. Chatterjea, Arkadev., Jerian, Joseph A., and Jarrow, Robert A. (2001). Market Manipulation and Corporate Finance: A new Perspectives, 1994 Annual Meeting Review, SouthWestern Finance Association, Texas, USA.

4. Chen RR, Chidambaran NK, Imerman MB, Sopranzetti BJ,Liquidity, Leverage, and Lehman: A Structural Analysis of Financial Institutions in Crisis, Fordham School of Business Research Paper No.2279686, 2013.

5. Cheng, L.Y., Wang, M.C., and Chen, K.C. (2014). Institutional Investment Horizons and the Stock Performance of Private Equity Placements: Evidence from the Taiwanese Listed Firms, Review of Pacific Basin Financial Markets and Policies, $17(2)$.

6. DeGennaro, Ramon P., Kim, Sangphill. (2003). The CAPM and Beta in an Imperfect Market, SSRN Working paper series

7. Dimitrov V, Jain PC. (2006). The Value Relevance of Changes in Financial Leverage, SSRN Working Paper

8. Emilios, A. (2015).Bank Leverage Ratios and Financial Stability: A Micro- and Macroprudential Perspective, Working Paper No.849, Levy Economics Institute

9. Eugene FF, French KR. (2004). The Capital Asset Pricing Model: Theory and Evidence,Journal of Economic Perspectives.

10. Galagedera, D.U.A. (2007).An alternative perspective on the relationship between downside beta and CAPM beta, Emerging Markets Review

11. Gunarathna, V. (2016).How does Financial Leverage Affect Financial Risk? An Empirical Study in Sri Lanka, Amity Journal of Finance, 1(1), 57-66.

12. Gunaratha V. (2013).The Degree of Financial Leverage as a Determinant of Financial Risk: An Empirical Study of Colombo Stock Exchange in Sri Lanka,2nd International Conference on Management and Economics Paper.

13. Khwaja, Asim Ijaz., and Mian, Atif. (2005).Unchecked intermediaries:Price manipulation in an emerging stock market, Journal of Financial Economics 78, $243-241$

14. Li, L., and Pornchai, C. (2014). Income Structure, Competitiveness, Profitability, and Risk: Evidence from Asian Banks, Review of Pacific Basin Financial Markets and Policies, 17(3).

15. Martin, K., and Sweder, V.W. (2012). On Risk, leverage and banks: Do highly leveraged banks take on excessive risk?, Discussion Paper TI 12-022/2/DSF31, Tinbergen Institute

16. Rahman, Dima. (2013). Are Banking Systems Increasingly Fragile? Investigating Financial Institutions' CDS Return Extreme Co-Movements, Quantitative Finance

17. Siller, Thomas. (2013). Measuring Marginal Risk Contributions in Credit Portfolios, Quantitative Finance

18. Umar. (2011). Profits, Financial Leverage and Corporate Governance,SSRN Working Paper

19. Narmania, Davit. "Economic Policy Uncertainty and Risk Management in Regulated Sectors." International Journal of Business and General Management (IJBGM) 7.4 (2018): 19-28.

20. Akintayo, Wole Lateef. "Adoption Of Sustainable Risk Management: A Study of Chemical Exposure in Textile Industry in Nigeria." International Journal of Textile and Fashion Technology (IJTFT) 5.3 (2013): 17-28.

21. Pal, Shrabanti. "Behaviour of Financial Metrics of Indian Steel Industry During Pre And Post Financial Crisis Period." International Journal of Financial Management (IJFM) 5.4 (2016): 11-22.

22. Derbali, Abdelkader, and Slaheddine Hallara. "Main determinants of banking profitability in Tunisia before and during the financial crisis of 2007." International Journal of Accounting and Financial Management Research (IJAFMR) 3.1 (2013): 39 56. 


\section{RESEARCH}

23. Ang, A., Chen, J. (2007). CAPM Over the Long Run: 1926-2001, Journal of Empirical Finance

24. $A D B$ and Viet Nam Fact Sheet, 2010

\section{OTHER WEB SOURCES}

25. http://www.ifc.org/ifcext/mekongpsdf.nsf/Content/PSDP22

26. http://www.construction-int.com/article/vietnam-construction-market.html

27. http://fia.mpi.gov.vn/Default.aspx?ctl=Article \&MenuID $=170 \&$ aID $=185 \&$ PageSize $=10 \&$ Page $=0$

28. http://kientruc.vn/tin_trong_nuoc/nganh-bat-dong-san-rui-ro-va-co-hoi/4881.html

29. http://www.bbc.co.uk/vietnamese/vietnam/story/2008/12/081226_vietnam_gdp_down.shtml

30. http://www.mofa.gov.vn/vi/

31. https://www.ceicdata.com/en/indicator/vietnam/real-gdp-growth 